\title{
INFLUENCE OF CYLINDER DESIGN ON ITS SPEED DURING CORN EAR THRESHING
}

Dainius STEPONAVIČIUS, Institute of Agricultural Engineering and Safety, Faculty of Agricultural Engineering, Aleksandras Stulginskis University, Studentų 15A, Akademija, Kaunas distr., Lithuania; dainius.steponavicius@asu.lt

Aurelija KEMZŪRAITE், Institute of Agricultural Engineering and Safety, Faculty of Agricultural Engineering, Aleksandras Stulginskis University, Studentų 15A, Akademija, Kaunas distr., Lithuania; aurelija.kemzuraite@ asu.lt (corresponding author)

Valdas KINIULIS, Institute of Agricultural Engineering and Safety, Faculty of Agricultural Engineering, Aleksandras Stulginskis University, Studentų 15A, Akademija, Kaunas distr., Lithuania; valdas.kiniulis@gmail.com

Albinas ANDRIUŠIS, Institute of Power and Transport Machinery, Faculty of Agricultural Engineering, Aleksandras Stulginskis University, Studentų 15, Akademija, Kaunas distr., Lithuania; albinas.andriusis@ asu.lt

Darius JUKNEVIČIUS, Institute of Agricultural Engineering and Safety, Faculty of Agricultural Engineering, Aleksandras Stulginskis University, Studentų 15A, Akademija, Kaunas distr., Lithuania; darius.juknevicius11@gmail.com

Technological and structural parameters of a threshing unit must ensure the highest possible quality of its operation under minimum input and cost. The aim of the study was to estimate the variation of speed of threshing cylinder with two different shapes of filler plates (FP-I and FP-II) under various corn ear feed rate into combine harvester.

Threshing cylinder speed (frequency of rotation) $n_{b}\left(\mathrm{~min}^{-1}\right)$ was measured simultaneously each $0.075 \mathrm{~s}$ using stationary tangential single-cylinder threshing unit located in laboratory-training ground intended for investigation into technological processes of agricultural machinery. Frequency of rotation of non-loaded threshing cylinder speed amounted for $450 \mathrm{~min}^{-1}$.

Increase in corn ear feed rate from $6 \mathrm{~kg} \mathrm{~s}^{-1}$ to $12 \mathrm{~kg} \mathrm{~s}^{-1}$ caused frequency of rotation of threshing cylinder to decrease from $n_{b}=437.82 \pm 0.21 \mathrm{~min}^{-1}$ to $n_{b}=420.96 \pm 0.50 \mathrm{~min}^{-1}$ (using FP-I). Replacing covered spaces between rasp bars with FP-II had no effect on cylinder speed - it has decreased from $438.06 \pm 0.23 \mathrm{~min}^{-1}$ to $421.37 \pm 0.32 \mathrm{~min}^{-1}$. Results showed that in case of FP-I, the amplitude of speed $A_{n b}$ has increased from $A_{n b}=4.07 \pm 0.44 \mathrm{~min}^{-1}$ to $A_{n b}=8.60 \pm 0.88 \mathrm{~min}^{-1}$, whereas in case of FP-II - from $A_{n b}=2.67 \pm 0.25 \mathrm{~min}^{-1}$ to $A_{n b}=4.52 \pm 0.62 \mathrm{~min}^{-1}$ in response to increased feed rate from $4 \mathrm{~kg} \mathrm{~s}^{-1}$ to $12 \mathrm{~kg} \mathrm{~s}^{-1}$. This means that using the covers FP-II the threshing apparatus will work more evenly. The average threshing cylinder speed, irrespective of the closure of spaces between rasp bars, was found to decrease by approx. $20 \mathrm{~min}^{-1}$ in result of increase in corn ear feed rate from $4 \mathrm{~kg} \mathrm{~s}^{-1}$ to $12 \mathrm{~kg} \mathrm{~s}^{-1}$. When threshing corn ears, irrespective of the shape of filler plates, the acceptable feed rate amounted for $10 \mathrm{~kg} \mathrm{~s}^{-1}$, as it caused to exceed the permissible limit of $5 \%$ allowed for decrease in cylinder speed $\left(n_{b}=427.5 \mathrm{~min}^{-1}\right)$.

Keywords: concave, corn ear, feed rate, threshing cylinder.

\section{INTRODUCTION}

A comprehensive analysis and investigation of threshing process is required to capture dynamic processes taking place within a threshing unit. These include speed of crop flow passing over the surface of the concave and forces acting on the concave, variation of threshing cylinder speed, required power and grain separation through concave as well as other parameters (Lipkovich, 1973, Lurje, 1981, Zhong et al., 2013).

One of the most important factors in the corn ears threshing process is the threshing cylinder speed, i.e., linear velocity of the rasp bars (Humberg et al., 2009). Higher speed than the optimum results in kernels damage and cobs break. Lower speed than the optimum results in kernel not separating from cobs, i.e., threshing cylinder loss, and can overload the separators and cleaning shoe (Petkevichius et al., 2008). The experimental research shows that the optimum velocity of rasp bars for corn ears threshing is $10-20 \mathrm{~m} \mathrm{~s}^{-1}$ (Miu, 2015). The operator of a combine harvester can control the efficiency of the threshing apparatus by changing the gap between the cylinder and the concave, by changing the rotational speed of the cylinder and by changing the feed rate of crop passing through the threshing unit, i.e., load of threshing apparatus (Špokas et al., 2013).

During the harvesting operation, the feed rate of crop material passed into the threshing unit of combine harvester is highly variable (Lurje, 1981). Because of this variation in cylinder speed occurs (Derevenko and Severin, 1991). The cylinder speed can increase or decrease due to load changes of threshing apparatus. A change in cylinder speed of more

Copyright (C) 2017 The Authors. Published by Aleksandras Stulginskis University. This is an open-access article distributed under the terms of the Creative Commons Attribution License (CC-BY 4.0), which permits unrestricted use, distribution, and reproduction in any medium, provided the original author and source are credited. 
than approx. five percent from the ideal speed would normally be considered unacceptable (Liubimov et al., 1999). Change in cylinder speed results in less than optimum combine harvester performance. It is expressed in increased kernel losses and kernel damage, excess strain on the components and wears on the threshing unit components (Grek, 1970).

One of the means for avoiding significant reduction in cylinder speed and increasing in cylinder loss is increase in a moment of inertia of the threshing cylinder (Lipkovich, 1973; Steponavičius et al., 2013). An application of constant crop flow system by controlling combine harvester ground speed could be assigned to the other means (Herlitzius, 2005). The constant feed rate can be achieved by changing the combine's speed. In the modern combine harvesters, the automatic driving speed system (constant crop flow system) evaluates the kernel loss of separators, cleaning shoe and the load of the threshing apparatus. Automatic systems change the combine harvester ground speed depending on crop yield, environmental conditions and other varying factors. They ensure the smooth flow of the crop supplied to the threshing apparatus. Such systems are used by New Holland (IntelliCruise TM), John Deere (Smart Harvest), Fendt (Constant Flow), Claas (Cruise Pilot), etc. However, the automatic control systems for combine ground speeds are expensive and are still being developed.

When harvesting corn crops for grains, the gaps between adjacent rasp bars of threshing cylinder are covered with filler plates, so that the mass being threshed could not be passed inside the cylinder. Fitting cylinder with filler plates was found to have a positive effect on wheat grain separation through the concave and enables to reduce grain damage (Kuzin, 2005). It was established also that the cylinder covering with the filler plates has a positive impact on corn kernel separation through the first part of concave when compared to the open cylinder (Kiniulis et al., 2017).

Aim of the research was to estimate the variation of speed of threshing cylinder with two different shapes of filler plates (FP-I and FP-II) under various corn ear feed rate into combine harvester.

\section{MATERIALS AND METHODS}

Threshing apparatus. Experimental trials were carried out in 2014-2015 at Laboratory for Investigation Technological Processes of Agricultural Machinery of the Institute of Agricultural Engineering and Safety using a stationary tangential single-cylinder threshing unit (Figure 1) comprised as follows: a belt feeder 1 of $10 \mathrm{~m}$ in length and $1.2 \mathrm{~m}$ in width used for feeding corn ear flow into the threshing unit; a tangential threshing cylinder 3 of $1.2 \mathrm{~m}$ in width and $0.6 \mathrm{~m}$ in diameter with eight rasp bars attached to it, which was wrapped in the grate-bar type concave 4 . For rotation of operating parts of the threshing unit, a $15 \mathrm{~kW}$ electric motor was used. Cylinder speed was controlled using a frequency transducer Delta VFD-C2000 SERIES and belt variator. Frequency of rotation of non-loaded threshing cylinder speed amounted for $450 \mathrm{~min}^{-1}$.

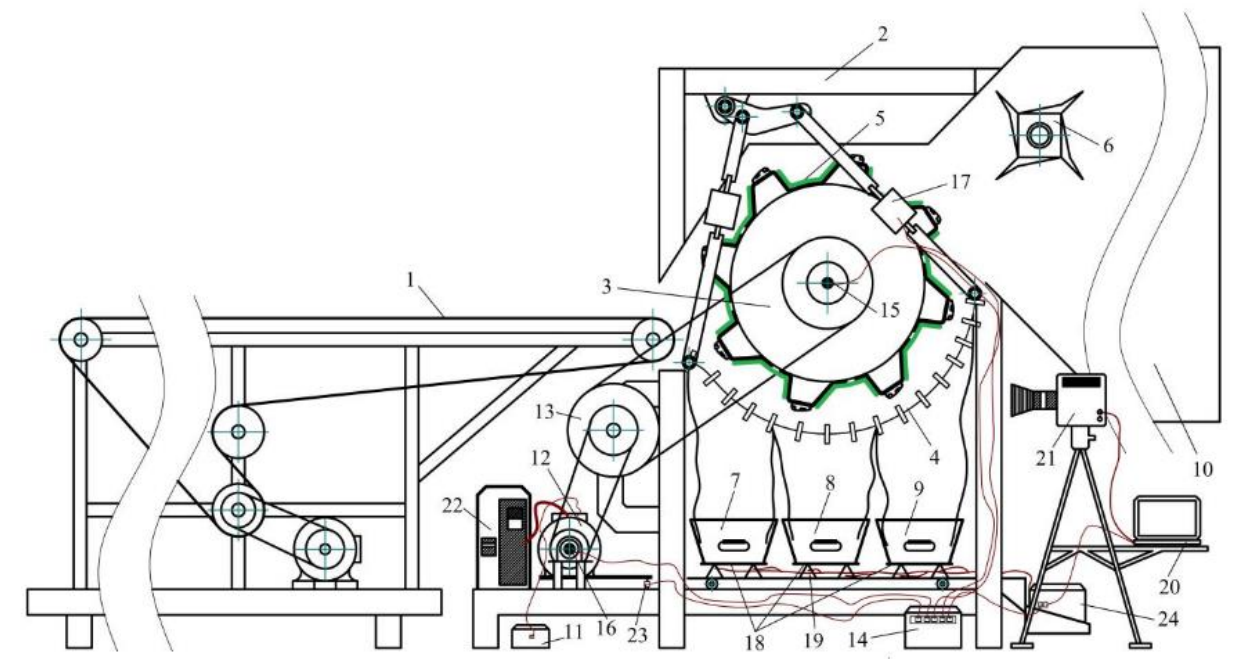

Figure 1. The scheme of the stationary unit used for threshing corn ears (Kiniulis et al., 2017):

1 - belt feeder, 2 - frame, 3 - threshing cylinder, 4 - concave, 5 - filler plates, 6 - back beater, 7, 8, 9 - tanks for collecting grains separated through individual sections of the concave, 10 - tailings collection tank, 11 - the device for measuring electric current, voltage and wattage, 12 electric motor $(15 \mathrm{~kW}), 13$ - belt variator, 14 - signal inverter PIC18F2553, 15 - optical sensor of threshing cylinder rotation speed Autonics E4OH, 16 - optical sensor of electric motor rotation speed Autonics E4OH, 17 - sensor of pressure force at the end of the concave Scaime ZFA $5000 \mathrm{~N}, 18$ -

electronic weighing scale, 19 - tenzoresistive load (weight) sensors, 20 - computer, 21 - a high-speed camera Photron 1024, 22 - frequency transducer, 23 - torque sensor Scaime ZFA 2000 N, 24 - signal amplification and power supply unit for weighing scale

For the purpose of measuring speed (frequency of rotation) of electric motor $n_{m}\left(\mathrm{~min}^{-1}\right)$ and of threshing cylinder $n_{b}\left(\mathrm{~min}^{-1}\right)$, optical sensors Autonics $E 40 H$ were attached to the shafts of motor and of cylinder (Figure 2a) and (Figure 2b). The speeds were measured simultaneously each $0.075 \mathrm{~s}$. Pulses obtained during rotation of shafts per time interval were calculated using counter of digital input of modified converter $K 8055 \mathrm{~N}$. To improve accuracy, time for calculation of revolutions was measured using the same counter for calculation of fixed-frequency signal. Resolution $-0.366 \mathrm{~ms}$. 


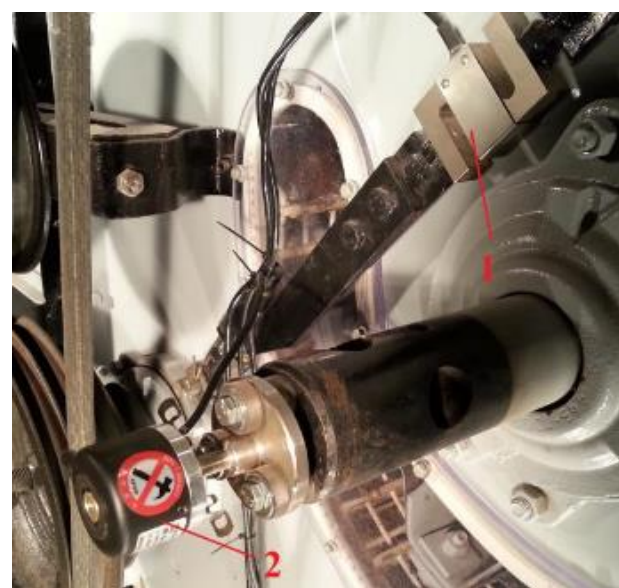

a)

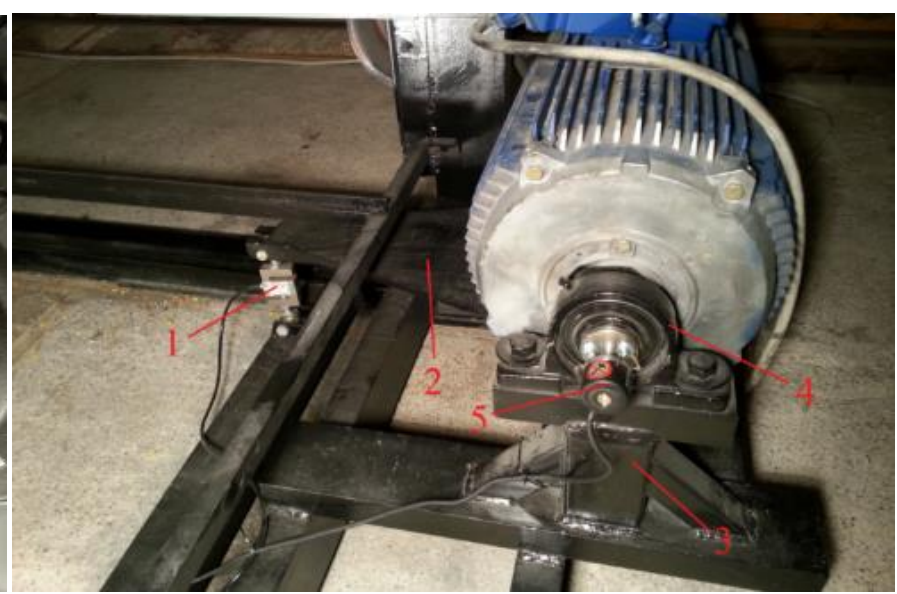

b)

Figure 2. Equipment for measurement of speed: a) of threshing cylinder, b) of electric motor

Analogue output signal of each sensor was amplified using a Scaime CPJ device for each sensor. For 12 bit resolution ADC the modified converter board $K 8055 \mathrm{~N}$ was used. Then, signal was transmitted via USB from converter to computer (20) (Figure 1) where it is further processed using the software ThreshLab (Figure 3). Using a converter, this software calculated mean value of force at pre-set time intervals (minimum recommended 20 ms). For this purpose while measuring at higher speed (of $1 \mathrm{~ms}$ ), a sample of pre-established size (5 values) was collected for each of sensors.

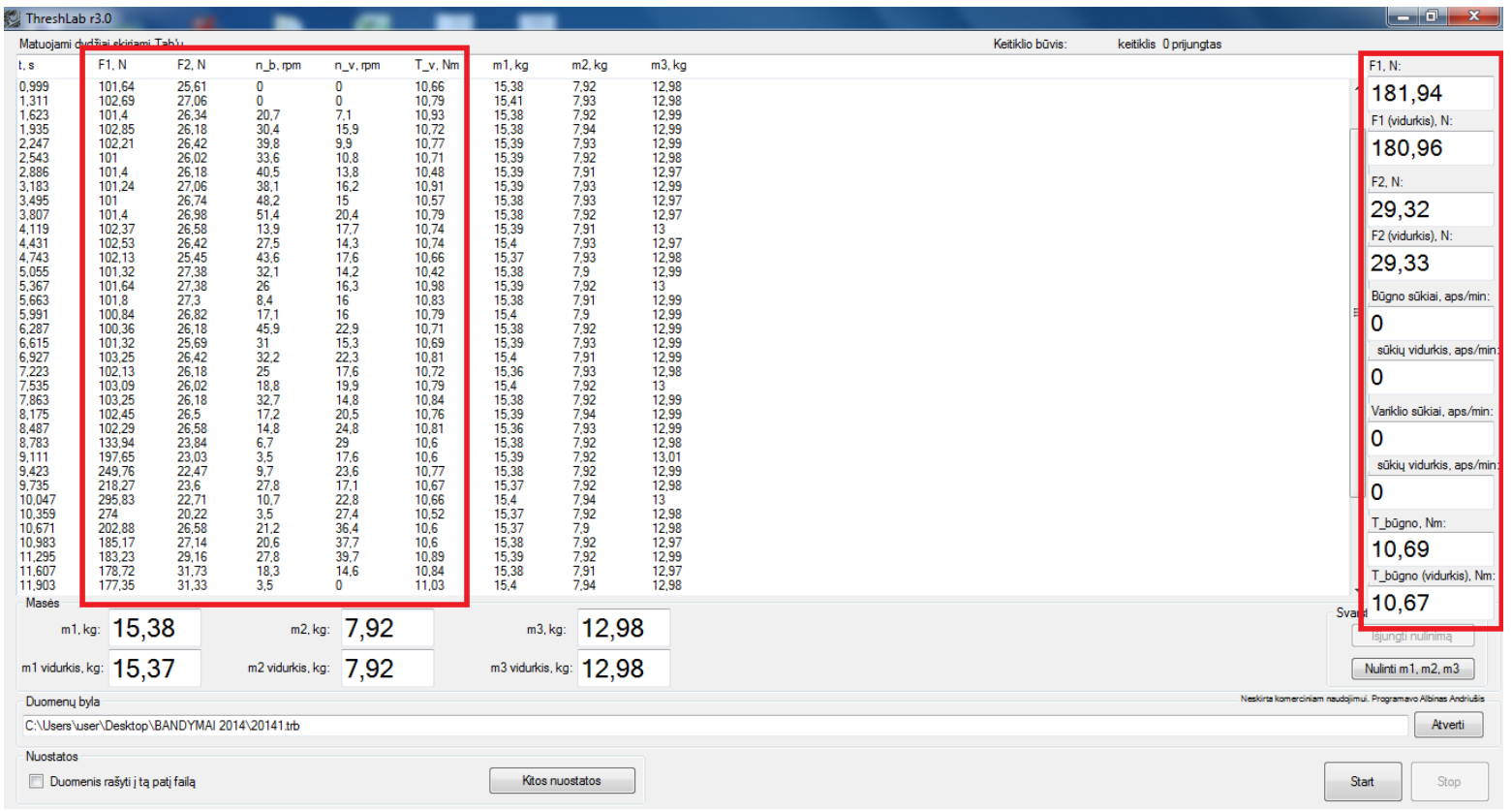

Figure 3. Window in ThreshLab software developed by A. Andriušis for investigation of threshing process

Having a sufficient number of measurements made (in this particular investigation 13.4 times per second or every $0.075 \mathrm{~s}$ ), variation of threshing cylinder speed $n_{b}$ was also precisely determined by taking into account dispersion of measurement values by means of standard deviation $\sigma$ and confidence interval of the average (e.g. by selected level of probability $95 \%$ ). Moreover, coefficient of variation $v$, average amplitude of variation $A_{n b}$, and coefficient of fluctuation $\delta$ under varied corn ear feed rate $q$ in range from 4 to $12 \mathrm{~kg} \mathrm{~s}^{-1}$ can be calculated too.

Speed of threshing cylinder $n_{b}$ during process of operation is randomly achieved maximum and minimum numerical values that are different. To estimate the variation of threshing cylinder speed more adequately, it is worth to calculate the coefficient of fluctuation as follows:

$$
\delta=\frac{n_{b \max 10}-n_{b \min 10}}{n_{b}}
$$

where $n_{b \max 10}$ - arithmetic average of maximum numerical values of threshing cylinder speed $n_{b}(10$ maximum values selected) in $\min ^{-1}$;

$n_{b \min 10}-$ arithmetic average of minimum numerical values of threshing cylinder speed $n_{b}(10$ minimum values selected $)$ in $\min ^{-1}$; 
$n_{b}-$ arithmetic average of all numerical values of threshing cylinder speed in $\min ^{-1}$.

Generalized maximum and minimum numerical values were used in calculations, i.e. arithmetic averages of 10 minimum and 10 maximum values. Having calculated averages of minimum and maximum numerical values of threshing cylinder speed $n_{b}$ allows for finding the average amplitude of speed variation from numerical values of arithmetic average of speed:

$$
A_{n b}=\frac{n_{b \max 10}-n_{b \min 10}}{2}
$$

Variation of threshing cylinder speed $n_{b}$ can also be characterized through period of its variation, i.e., period of time between two adjacent maximum numerical values of speed $n_{b}$. Like frequency of variation, this parameter is also difficult to determine as they both obtain variable values during process of threshing.

Experimental trials of corn ear threshing were performed using threshing cylinder fitted with $1.5 \mathrm{~mm}$ width and $2.54 \pm 0.21 \mathrm{~kg}$ mass filler plates made of stainless steel. They were attached to threshing cylinder by means of steel rivets. The standard cylinder of threshing unit (Figure 1) with the cross-section area of one space between rasp bars amounting for $119.91 \mathrm{~cm}^{2}$ (using FP-I), whereas the same cross-section area amounts for $105.27 \mathrm{~cm}^{2}$ after the filler plate FP-II is fitted (Figure 4), meaning the area is reduced by $12.2 \%$.

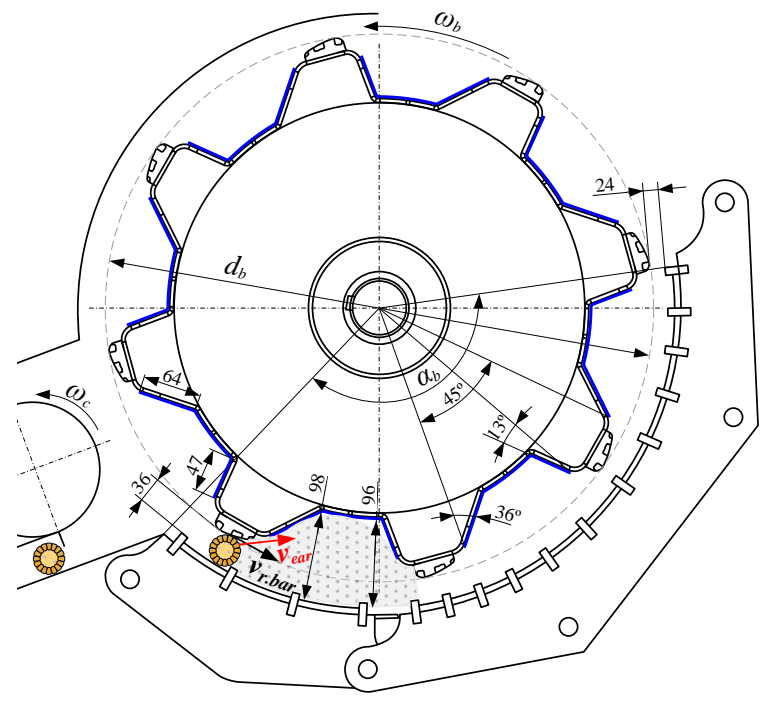

a)

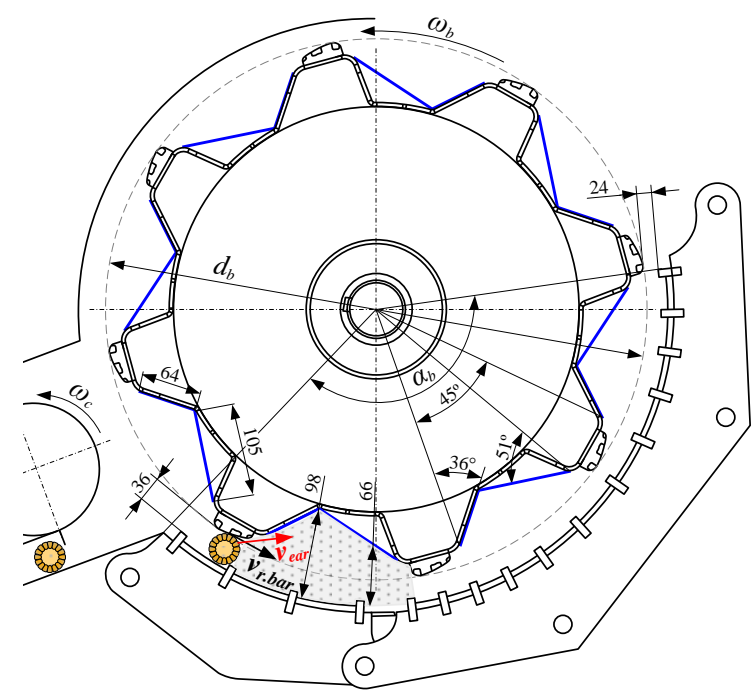

b)

Figure 4. Filler plates of threshing cylinder: a) FP-I, b) FP-II: $\omega_{b}$ - angular velocity of the cylinder; $\omega_{c}$-angular velocity of the feeder conveyor; $d_{b}$ - diameter of the cylinder; $\alpha_{b}$ - concave wrapping angle; $v_{r . b a r}$ - linear velocity of rasp bars; $v_{e a r}-$ speed of corn ear

Biometrical indicators. During the research, corn ear biometrical indicators were determined. Corn ears of Rodney species were weighted in the laboratory by measuring their length, diameter and determining the number of grain vertical rows and horizontal rings, total number of grains on one ear and weight of 1000 grains. Corn ears were threshed in the threshing unit concerned at their physiological maturity stage with the grain moisture content of $30.49 \pm 0.60 \%$, moisture content of ear cobs of $54.85 \pm 1.31 \%$ and that of the corn ear-covering leaves of $27.51 \pm 2.41 \%$. Moisture levels of leaves, grains, and cobs were determined by drying them in a $105^{\circ} \mathrm{C}$ temperature drying chamber until air-dry mass was achieved. Moisture percentage was calculated based on the difference in the masses of wet and dried grains.

Statistical evaluation of research data. Every test was repeated three times. Experimental data has been processed in accordance with the statistical methods. The average value of the records and their confidence intervals $(P=0.05)$ were given (Olsson et al., 2000). To establish the correlation of two factors, the curvilinear correlation coefficient $R^{2}$ was calculated. Fisher's criterion was used to find the curvilinear correlation of two factors. Regression equations were used to calculate the direction and size of the factor correlation.

\section{RESULTS AND DISCUSSION}

Based on the threshing tests it has been established that increase in corn ear feed rate from $6 \mathrm{~kg} \mathrm{~s}^{-1}$ to $12 \mathrm{~kg} \mathrm{~s}^{-1}$ caused frequency of cylinder rotation to decrease from $n_{b}=437.82 \pm 0.21 \mathrm{~min}^{-1}$ to $n_{b}=420.96 \pm 0.50 \mathrm{~min}^{-1}$ (using FP-I) (Figure 5a). Frequency of rotation of non-loaded threshing cylinder speed amounted for $450 \mathrm{~min}^{-1}$. Replacing covered spaces between rasp bars with FP-II (Figure 5b) had no effect on cylinder speed - it has decreased from $438.06 \pm 0.23 \mathrm{~min}^{-}$ ${ }^{1}$ to $421.37 \pm 0.32 \mathrm{~min}^{-1}$. 


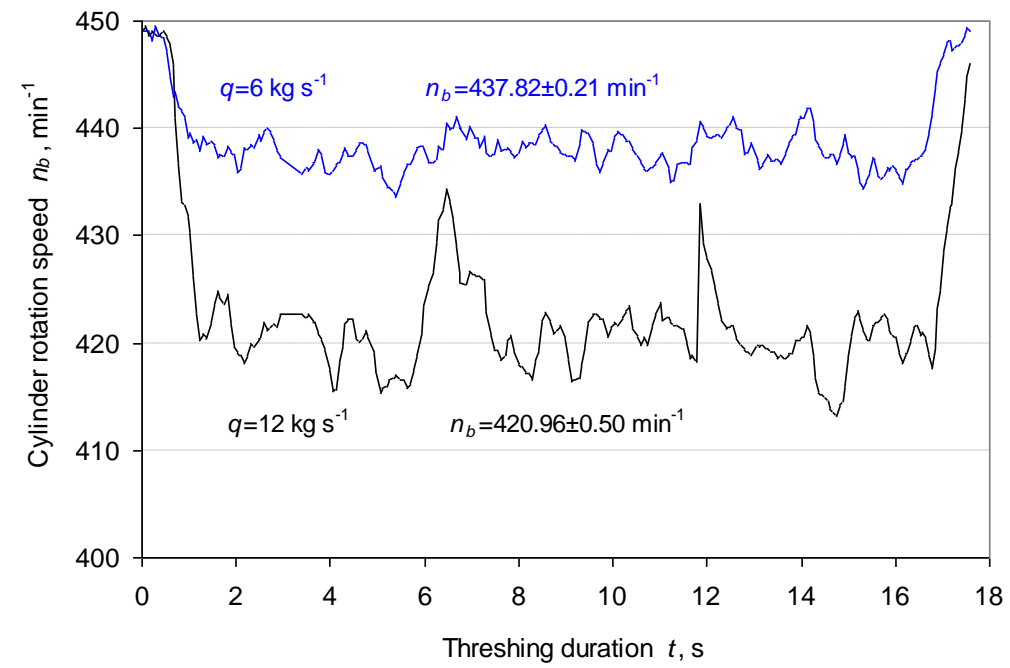

a)

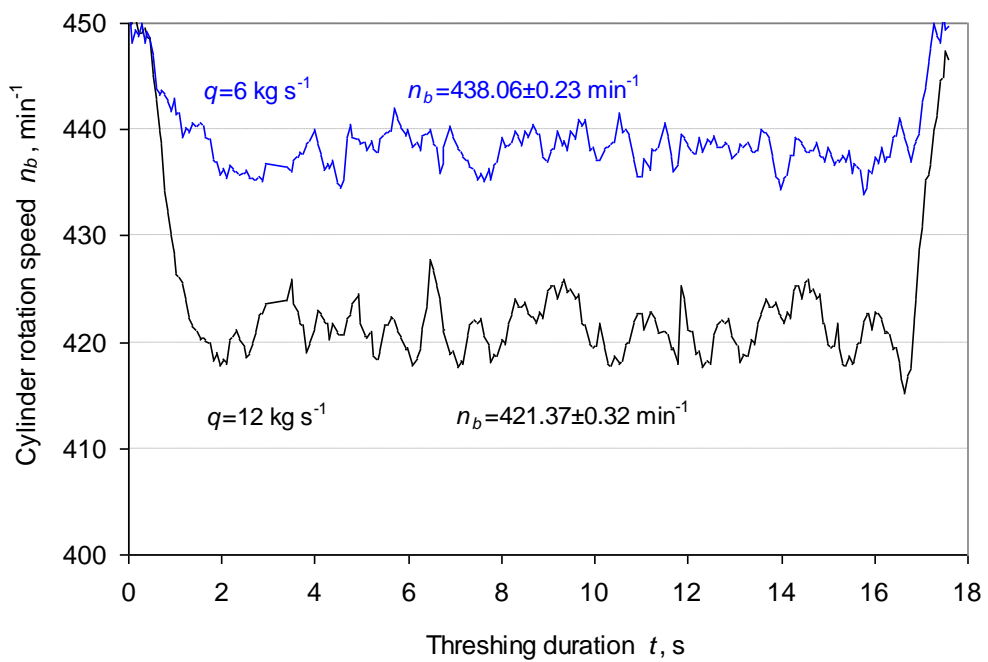

b)

Figure 5. Variation in threshing cylinder speed $n_{b}$ at feed rate of $6 \mathrm{~kg} \mathrm{~s}^{-1}$ and $12 \mathrm{~kg} \mathrm{~s}^{-1}$ of corn ears using threshing cylinder fitted with FP-I (a) and FP-II (b)

Statistical processing and systematization of obtained findings results in data provided in Tables 1 and 2. Tables represent arithmetic averages for each individual repetition and total average for all the repetitions. Moreover, amplitudes of their variation, coefficient of variation and coefficient of fluctuation were calculated too, depending on feed rate $q$ varied in range from $4 \mathrm{~kg} \mathrm{~s}^{-1}$ to $12 \mathrm{~kg} \mathrm{~s}^{-1}$. Tables 1 and 2 contain the data presenting that in case of covered spaces between rasp bars with FP-I, the amplitude of speed has increased from $A_{n b}=4.07 \pm 0.44 \mathrm{~min}^{-1}$ to $A_{n b}=8.60 \pm 0.88$ $\mathrm{min}^{-1}$, whereas in case of FP-II - from $A_{n b}=2.67 \pm 0.25 \mathrm{~min}^{-1}$ to $A_{n b}=4.52 \pm 0.62 \mathrm{~min}^{-1}$ in response to increased feed rate from $4 \mathrm{~kg} \mathrm{~s}^{-1}$ to $12 \mathrm{~kg} \mathrm{~s}^{-1}$. The amplitude of the speed variation determines the uniformity of the threshing cylinder rotation. This means that using the covers FP-II the threshing apparatus will work more evenly.

Table 1. The effect of feed rate $q$ on cylinder speed $n_{b}$ when using cylinder with covered spaces between rasp bars by FP-I

\begin{tabular}{|l|c|c|c|c|c|}
\hline \multirow{2}{*}{ Indices } & \multicolumn{3}{|c|}{ Feed rate $q, \mathrm{~kg} \mathrm{~s}^{-1}$} \\
\cline { 2 - 6 } & $\mathbf{4}$ & $\mathbf{6}$ & $\mathbf{8}$ & $\mathbf{1 0}$ & $\mathbf{1 2}$ \\
\hline Average of speed repetition $1, n_{b}, \mathrm{~min}^{1}$ & 437.62 & 437.42 & 433.74 & 427.37 & 421.06 \\
\hline Average of speed repetition $2, n_{b}, \mathrm{~min}^{1}$ & 441.79 & 438.18 & 432.39 & 426.95 & 421.69 \\
\hline Average of speed repetition $3, n_{b}, \mathrm{~min}^{1}$ & 441.84 & 437.86 & 432.34 & 427.35 & 420.13 \\
\hline Average of speed, $\boldsymbol{n}_{\boldsymbol{b}}, \mathbf{m i n}^{1}$ & $\mathbf{4 4 0 . 4 2}$ & $\mathbf{4 3 7 . 8 2}$ & $\mathbf{4 3 2 . 8 2}$ & $\mathbf{4 2 7 . 2 2}$ & $\mathbf{4 2 0 . 9 6}$ \\
\hline Standard deviation, $\sigma, \mathrm{min}^{1}$ & 2.26 & 1.55 & 1.99 & 3.14 & 3.68 \\
\hline Confidence level at 95\% $( \pm)$ & 0.31 & 0.21 & 0.27 & 0.42 & 0.23 \\
\hline Coefficient of variation,,$\%$ & 0.51 & 0.35 & 0.46 & 0.73 & 0.87 \\
\hline Amplitude of variation, $A_{n b}, \min ^{1}$ & 4.07 & 6.82 & 4.37 & 6.27 & 8.60 \\
\hline Coefficient of fluctuation, $\delta$ & 0.018 & 0.031 & 0.020 & 0.029 & 0.041 \\
\hline
\end{tabular}


Table 2. The effect of feed rate $q$ on cylinder speed $n_{b}$ when using cylinder with covered spaces between rasp bars by FP-II

\begin{tabular}{|l|c|c|c|c|c|}
\hline \multirow{2}{*}{ Indices } & \multicolumn{5}{|c|}{ Feed rate $q, \mathrm{~kg} \mathrm{~s}^{-1}$} \\
\cline { 2 - 6 } & $\mathbf{4}$ & $\mathbf{6}$ & $\mathbf{8}$ & $\mathbf{1 0}$ & $\mathbf{1 2}$ \\
\hline Average of speed repetition $1, n_{b}, \mathrm{~min}^{1}$ & 441.62 & 438.16 & 433.44 & 426.97 & 421.28 \\
\hline Average of speed repetition $2, n_{b}, \mathrm{~min}^{1}$ & 441.57 & 438.22 & 432.49 & 427.27 & 421.58 \\
\hline Average of speed repetition $3, n_{b}, \mathrm{~min}^{1}$ & 441.56 & 437.78 & 433.44 & 427.00 & 421.25 \\
\hline Average of speed, $\boldsymbol{n}_{\boldsymbol{b}}, \mathbf{m i n}^{1}$ & $\mathbf{4 4 1 . 5 8}$ & $\mathbf{4 3 8 . 0 6}$ & $\mathbf{4 3 3 . 1 2}$ & $\mathbf{4 2 7 . 0 8}$ & $\mathbf{4 2 1 . 3 7}$ \\
\hline Standard deviation, $\sigma, \min ^{1}$ & 1.28 & 1.67 & 2.57 & 2.76 & 2.36 \\
\hline Confidence level at 95\% $( \pm)$ & 0.17 & 0.23 & 0.35 & 0.37 & 0.16 \\
\hline Coefficient of variation, $v, \%$ & 0.29 & 0.38 & 0.59 & 0.65 & 0.56 \\
\hline Amplitude of variation, $A_{n b}, \min ^{1}$ & 2.67 & 3.29 & 5.30 & 5.59 & 4.52 \\
\hline Coefficient of fluctuation, $\delta$ & 0.012 & 0.015 & 0.024 & 0.026 & 0.021 \\
\hline
\end{tabular}

The average cylinder speed irrespective of type of closure of spaces between rasp bars, with the increasing of feed rate from $4 \mathrm{~kg} \mathrm{~s}^{-1}$ to $12 \mathrm{~kg} \mathrm{~s}^{-1}$, has decreased from $n_{b}=440.42 \pm 0.31 \mathrm{~min}^{-1}$ to $n_{b}=420.96 \pm 0.23 \mathrm{~min}^{-1}$ (using FP-I) and from $n_{b}=441.58 \pm 0.17 \mathrm{~min}^{-1}$ to $n_{b}=421.37 \pm 0.16 \mathrm{~min}^{-1}$ (using FP-I). Decrease in cylinder speed after covering spaces between rasp bars with filler plates resembling the shape of the threshing cylinder (FP-I) has increased from $\Delta n_{b}=1.76 \%$ to $\Delta n_{b}=6.24 \%$ (Figure 6a), whereas after covering with FP-II - its value decreased from $1.74 \%$ to $6.16 \%$ (Figure $6 \mathrm{~b}$ ). Acceptable value of decrease in threshing cylinder speed is 5\% (Liubimov et al., 1999). When threshing corn ears, the acceptable feed rate amounted for approx. $10 \mathrm{~kg} \mathrm{~s}^{-1}$ irrespective of the shape of filler plates covering spaces between rasp bars. In this case, it would not be exceeded the permissible limit of 5\% allowed for decrease in cylinder speed (to $\left.n_{b}=427.5 \mathrm{~min}^{-1}\right)$.

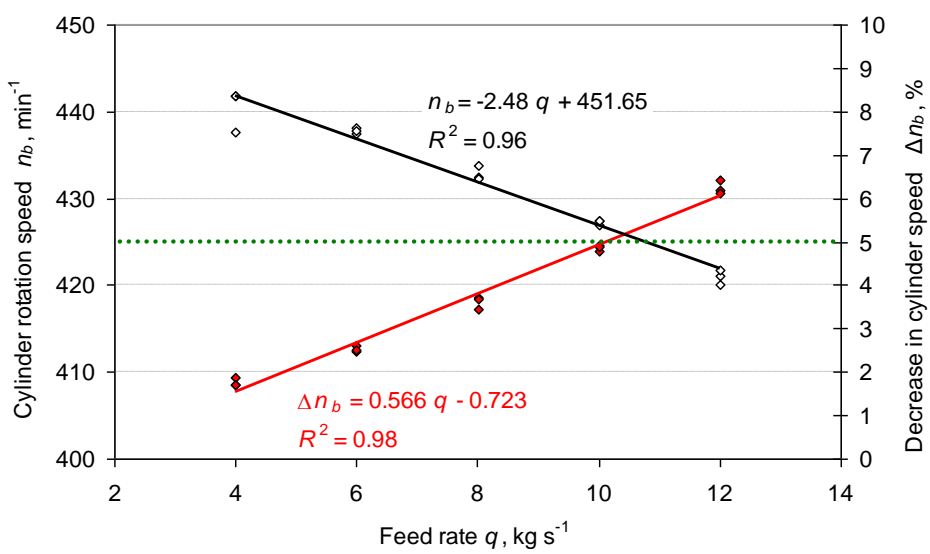

a)

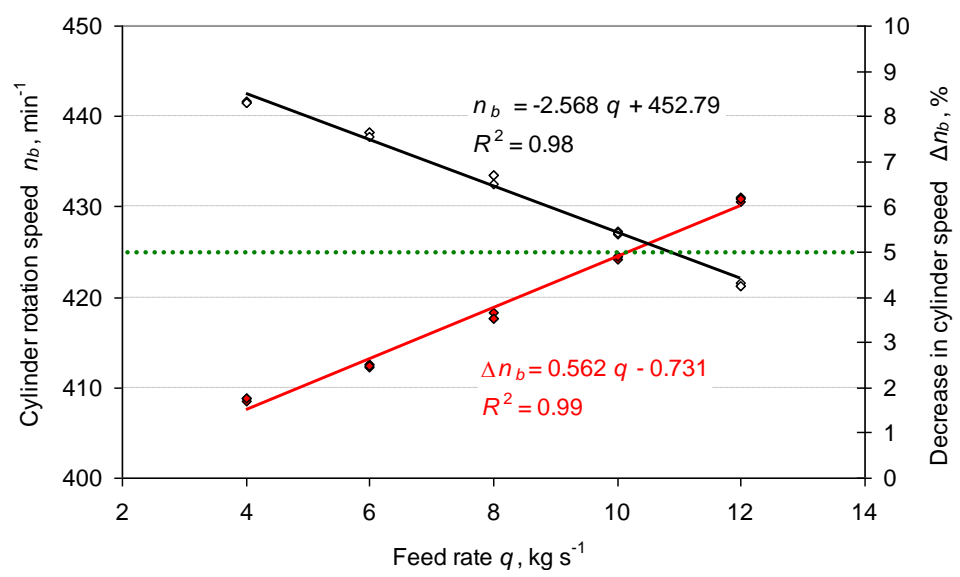

b)

Figure 6. The average cylinder speed $\mathrm{n}_{\mathrm{b}}$ and its decrease $\Delta \mathrm{n}_{\mathrm{b}}$ when using threshing cylinder with fitted with FP-I (a) and FP-II (b)

Threshing cylinder speed at peaks irrespective of type of closure of spaces between rasp bars, in result of increased feed rate from $4 \mathrm{~kg} \mathrm{~s}^{-1}$ to $12 \mathrm{~kg} \mathrm{~s}^{-1}$ was found to decrease from $n_{b}=437.58 \pm 0.26 \mathrm{~min}^{-1}$ to $n_{b}=414.97 \pm 0.18 \mathrm{~min}{ }^{-1}$ (using FPI) and from $n_{b}=439.01 \pm 0.13 \mathrm{~min}^{-1}$ to $n_{b}=417.65 \pm 0.14 \mathrm{~min}^{-1}$ (using FP-II). However, the decrease in threshing cylinder speed after closure of spaces between rasp bars with FP-I has increased from $\Delta n_{b}=2.39 \%$ to $\Delta n_{b}=7.58 \%$ ), and after fitting FP-II its value varied from $\Delta n_{b}=2.31 \%$ to $\Delta n_{b}=6.99 \%$. 


\section{CONCLUSIONS}

1. Increase in corn ear feed rate from $6 \mathrm{~kg} \mathrm{~s}^{-1}$ to $12 \mathrm{~kg} \mathrm{~s}^{-1}$ caused speed of threshing cylinder, covered with FP-I, rotation to decrease from $437.82 \pm 0.21 \mathrm{~min}^{-1}$ to $420.96 \pm 0.50 \mathrm{~min}^{-1}$. Replacing FP-I with FP II had no effect on cylinder speed - it has decreased from $438.06 \pm 0.23 \mathrm{~min}^{-1}$ to $421.37 \pm 0.32 \mathrm{~min}^{-1}$.

2. Results showed that in case of covered spaces between rasp bars with FP-I, the amplitude of speed $A_{n b}$ has increased from $4.07 \pm 0.44 \mathrm{~min}^{-1}$ to $8.60 \pm 0.88 \mathrm{~min}^{-1}$, whereas in case of FP II - from $2.67 \pm 0.25 \mathrm{~min}^{-1}$ to $4.52 \pm 0.62 \mathrm{~min}^{-1}$ in response to increased feed rate from $4 \mathrm{~kg} \mathrm{~s}^{-1}$ to $12 \mathrm{~kg} \mathrm{~s}^{-1}$. Based on these results, the process of corn ear threshing may be considered to be more even when threshing cylinder is fitted with FP-II.

3. The average of threshing cylinder speed, irrespective of the closure of spaces between rasp bars, was found to decrease by approx. $20 \mathrm{~min}^{-1}$ in result of increase in corn ear feed rate from $4 \mathrm{~kg} \mathrm{~s}^{-1}$ to $12 \mathrm{~kg} \mathrm{~s}^{-1}$. The acceptable feed rate amounted for $10 \mathrm{~kg} \mathrm{~s}^{-1}$, as it caused to exceed the permissible limit of cylinder speed of $5 \%$.

\section{REFERENCES}

1. Derevenko, V.V., Severin, Y.D. 1991. Machines for Harvesting of Grain Crops: Theory and Calculation, Publishing Kuban Agrarian University, Krasnodar [In Russian].

2. Grek, A. I. 1970. Issues Regarding Threshing, Vladivostok [In Russian].

3. Herlitzius, T. 2005. Combined Process Data Collection Using the Example of John Deere i-Series Features HarvestSmart and Auto Trac. VDI-MEG Kolloquium "Landtechnik", Book S, 183-190, Hohenheim [In German].

4. Humberg, D.S., Nicolai, R.E., Reitsma, K.D. 2009. Corn Grain Harvest. In: Clay, D. E., Reitsma, K. D., Clay, S. A. (eds.). Best Management Practices for Corn Production in South Dakota. EC929. South Dakota State University, South Dakota Cooperative Extension Service, Brookings, SD, pp. 93-98. http://openprairie.sdstate.edu/extension_circ/501.

5. Kiniulis, V., Steponavičius, D., Andriušis, A., Kemzūraitè, A., Jovarauskas, D. 2017. Corn Ear Threshing Performance of FillerPlate-Covered Threshing Cylinders. Mechanics, Vol. 23, No. 5, pp. 714-722. https://doi.org/10.5755/j01.mech.23.5.17389

6. Kuzin, G. A. 2005. Alternative Threshing: The Direction of Improvement of the Harvester. Vestnik Donskogo Gos Uni, 5, pp. 683691 [In Russian].

7. Lipkovich, E. I. 1973. Processes of Threshing and Separation in Threshing Apparatuso Combine Harvesters, VNIPTIMESH, Zernograd [In Russian].

8. Liubimov, A. I., Vockij, Z. I., Blednyh, V. V., Rahimov, R. S. 1999. Study on Agricultural Machinery, Kolos, Moscow [In Russian].

9. Lurje, A. B. 1981. Statistical Dynamics of Agricultural Machinery, Kolos, Moscow [In Russian].

10. Miu, P. I. 2015. Cereal Threshing and Separating Processes: Threshing Units. In: Miu, P. (ed.) Theory, Modelling, and Design. CRC Press, pp. 189-260. https://doi.org/10.1201/b18852-6

11. Olsson, U., Engstrand, U., Rupšys, P. 2000. Statistical Methods SAS and MINITAB, LŽŪU leidybos centras, Akademija [In Lithuanian].

12. Petkevichius, S., Shpokas, L., Kutzbach, H. D. 2008. Investigation of the Maize Ear Threshing Process. Biosystems Engineering, Vol. 99, pp. 532-539.https://doi.org/10.1016/j.biosystemseng.2008.01.002

13. Špokas, L., Steponavičius, D., Butkus, V., Kiniulis, V. 2013. Substantiation of the Rational Technological Parameters for Threshing High-moisture Corn Ears. Proceedings of the $6^{\text {th }}$ International Scientific Conference "Rural Development 2013", Vol. 6, Book 3, pp. 139-146, Aleksandras Stulginskis University, Lithuania.

14. Steponavičius, D., Butkus, V., Kiniulis, V., Karitonas, T., Bauša, L., Pužauskas, E. 2013. Influence of Inertia Momentum of Cylinder on Power Consumption during Corn Ear Threshing. Proceedings of the $12^{\text {th }}$ International Scientific Conference "Engineering for Rural Development", Vol. 12, pp. 66-72, Latvia University of Agriculture, Latvia.

15. Zhong, T., Yaoming, L., Chenghong, W. 2013. Experiments on Variable-Mass Threshing of Rice in the Tangential-LongitudinalFlow Combine Harvester. Journal of Agricultural Science and Technology, Vol. 15, pp. 1319-1334. 